\title{
FAST, REGIONAL CONDUIT FLOW TO AN EXCEPTIONAL-VALUE SPRING-FED CREEK: IMPLICATIONS FOR SOURCE-WATER PROTECTION IN MANTLED KARST OF SOUTH-CENTRAL PENNSYLVANIA
}

\author{
Todd M. Hurd ${ }^{1}$, Ashley Brookhart-Rebert², Thomas P. Feeney³, Martin H. Otz4, And Ines Otz ${ }^{5}$
}

\begin{abstract}
Karst springs of Cumberland County, Pennsylvania, are important water resources, but their sources and flow paths are unknown. We traced flow in a mantledkarst groundwater system in the Great Valley section of the Valley and Ridge Physiographic Province using fluorescent dyes, with focus on Big Spring Creek. Upper Big Spring Creek is assigned High Quality/Exceptional Value status by Pennsylvania based on its high water quality and value as a multi-use resource with exceptional recreational or ecological significance. Subsurface flow followed the geologic strike after Sulpho Rhodamine B (Acid Red 52) dye was released on exposed carbonates. Subsurface flow had a maximum effective linear velocity of $2.5 \mathrm{~km} \mathrm{~d}^{-1}$, which is 8 times greater than sodium fluorescein (Acid Yellow 73) dye released separately into a losing stream over colluvium $\left(0.3 \mathrm{~km} \mathrm{~d}^{-1}\right)$. Sulpho Rhodamine B was detected strongly $8.9 \mathrm{~km}$ away at Big Spring Creek's largest source spring ( $\sim 250$ ppt water; $50 \mathrm{ppb}$ eluate), but weakly in an east source ( $2.5 \mathrm{ppb}$ eluate). Sodium fluorescein was detected after four weeks at 0.07 to $0.15 \mathrm{ppb}$ in eluate at springs at Huntsdale Hatchery, $9.5 \mathrm{~km}$ from release atop the colluvial mantle. Slow flow derived from losing streams on the colluvial mantle likely maintains water quality of Big Spring Creek and similar systems. However, this recharge is distant, and the flow passes below karst recharge features in the valley center, creating many opportunities for contamination. Future studies of contaminant and sediment loadings to subterranean basins and of source-water protection strategies that recognize these patterns are necessary to protect these streams.
\end{abstract}

\section{INTRODUCTION}

Limestone springs and spring-fed creeks in southcentral Pennsylvania are well known as valuable coldwater fisheries supporting wild trout (e.g., Letort Spring Run, Big Spring Creek), and some are utilized as water supplies for trout hatcheries (Hurd et al., 2008) and municipalities. Nevertheless, source areas for these springs remain largely undetermined. Specific reaches of several spring-fed creeks are designated Exceptional Value Waters, Pennsylvania's most distinguished category of water use (Pennsylvania Code Chapter 93), even though groundwater contributes substantial quantities of non-point nitrogen and pesticide pollution to springs and wells in the region (Lindsey et al., 2003; Lindsey et al., 2009). Lindsey et al. (2009) note that in the Ridge and Valley Aquifer, more than $10 \%$ of well samples contained over six pesticides. Moreover, nitrate levels in groundwater of the MidAtlantic region are highest in areas mapped as carbonate rocks (Greene et al., 2004; Low and Chichester, 2006). Spring-fed creeks consistently show elevated nitrate, with highest concentrations of 6 to $8 \mathrm{mg} \mathrm{L}^{-1}$ in summer (Walderon and Hurd, 2009), and localized, rapid volatile organic compounds (VOCs) contamination of springs and wells has occurred via preferential flow in the region's karst (Aley et al., 2004).
The Cumberland Valley of south-central Pennsylvania is a complex regolith-mantled carbonate hydrogeological system located in the central part of the Great Valley section of the Valley and Ridge Physiographic Province. The valley is bordered to the north by North or Blue Mountain and to the south by South Mountain (Blue Ridge Physiographic Province), a resistant upland source of quartzite and schist (Chichester, 1996). Conodoguinet Creek and Yellow Breeches Creek drain Cumberland County between North and South Mountains. Flow is east-northeast into the Susquehanna River (Fig. 1). Most of the valley carbonates, and almost all of the shale near North Mountain, are in the Conodoguinet Creek basin. South Mountain and much of the eastern quarter of Cumberland Valley are drained by the Yellow Breeches Creek (Becher and Root, 1981). Several tributaries farther

\footnotetext{
${ }^{1}$ Corresponding Author - Shippensburg University Department of Biology, 1871 Old Main Drive, Shippensburg, Pennsylvania 17257, tmhurd@ship.edu

${ }^{2}$ Pennsylvania Department of Conservation and Natural Resources, Bureau of Recreation and Conservation, P.O. Box 8475, Harrisburg, PA 17105-8475, arebert@state.pa.us

${ }^{3}$ Shippensburg University Department of Geography and Earth Science, 1871 Old Main Drive, Shippensburg, Pennsylvania 17257, tpfeen@ship.edu

${ }^{4}$ Nano Trace Technologies, Gartenstrasse 6, CH-3252 Worben, Switzerland, mhotz@nanotracetech.com

${ }^{5}$ Nano Trace Technologies, 5858 East Molloy Road, Suite 171, Syracuse, New York 13211, iotz@nanotracetech.com
}

Journal of Cave and Karst Studies, December 2010 •129 
FAST, REGIONAL CONDUIT FLOW TO AN EXCEPTIONAL-VALUE SPRING-FED CREEK: IMPLICATIONS FOR SOURCE-WATER PROTECTION IN MANTLED KARST of South Central Pennsylvania

to the southwest originate on South Mountain and flow into the Conodoguinet Creek (Earle, 2009) via Burd Run and Middle Spring along the western boundary of Cumberland County. The Burd Run/Middle Spring system forms the only continuous surface stream between South Mountain and Conodoguinet Creek, and accessible caves are clustered within its surface watershed (Smeltzer, 1958). The southern half of the valley is underlain primarily by a sequence of carbonate rocks of variable thickness, collectively referred to as the Cumberland Valley sequence (Becher and Root, 1981). A thick wedge of colluvium on the north flank of South Mountain covers the older rocks in this sequence (Becher and Root, 1981) and reaches up to $137 \mathrm{~m}$ thick (Chichester, 1996). This mantle thins toward the valley center to reveal some carbonate outcrops. Hollyday et al. (1997) describe this mantled karst as part of the larger regional Elkton Aquifer or West Toe Aquifer of the western Blue Ridge Aquifer. Seepage-run data indicate that Yellow Breeches Creek is losing its water through the mantle to the underlying carbonates, and most stream reaches in the lower and middle part of the basin are gaining water from the groundwater system (Chichester, 1996). Other low-order tributaries sink near the carbonate contacts, suggesting complexity of recharge to the karst aquifer and in flow patterns to the spring-fed creeks that discharge in the valley center (Fig. 1). Typical karst features occur in the valley, including closed depressions, caves, sinking streams, springs, and dry channels. Direct groundwater-recharge features include sinkholes, fractured bedrock, sinking streams, and sinkhole ponds. Triassic-age diabase dikes that extend north/south through the valley act as groundwater dams and diversions in a few locations, and many of the springs discharge at faults or where diabase dikes cross the valley (Chichester, 1996).

The primary objective of this study was to determine source areas for Big Spring Creek, a valued wild-brook trout fishery (Cooper and Scherer, 1967) and water supply with increased development within its surface watershed. Big Spring Creek is designated an Exceptional Value Stream and exhibits complex karst hydrology. Big Spring Creek has two major source springs, with generally low variation in discharge, temperature, and turbidity (USGS, 2009), but occasionally with increased turbidity in the larger source spring in response to storms. A third contributing spring to Big Spring Creek serves as the municipal water supply to Newville, Pennsylvania. Becher and Root (1981) and Chichester (1996) suggested that surface water is lost to the groundwater system from South Mountain/Yellow Breeches Creek and flows through the karst of the Cumberland Valley toward north-flowing springs, including Big Spring. We sought to delineate a portion of Big Spring Creek's source areas with fluorescent dye tracing, including tracer release points in a colluvial losing reach in the upper Yellow Breeches watershed directly to the south and in a failed storm-water detention basin (sink collapse) in exposed carbonates farther west.

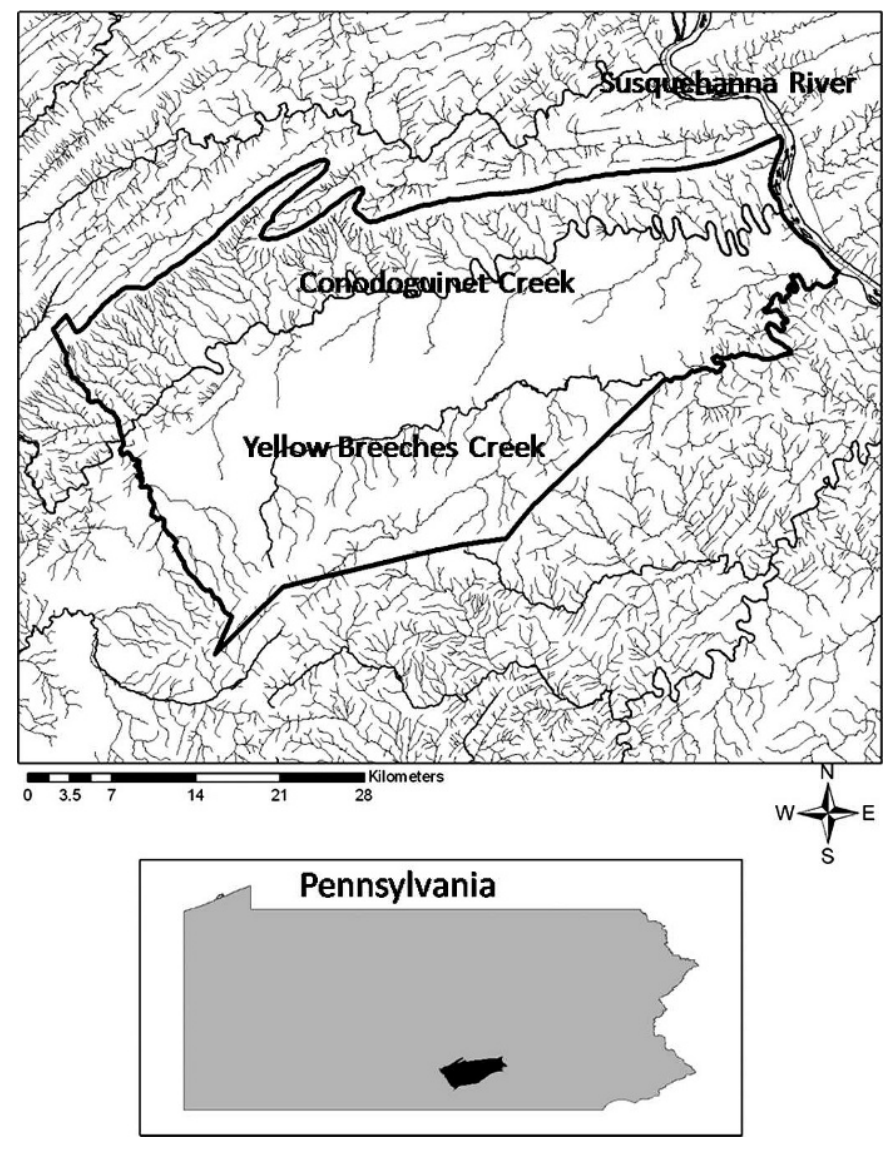

Figure 1. Study region showing boundary of Cumberland County in south-central Pennsylvania and major tributaries of the Susquehanna River within the carbonate valley (Conodoguinet and Yellow Breeches Creeks).

These contrasting release points also facilitated an initial comparison of groundwater-flow characteristics between mantled karst and exposed carbonates of the Great Valley section of the Valley Ridge Province in Cumberland County, Pennsylvania.

\section{Methods}

Eight springs were sampled for dye breakthrough, including the two main sources of Big Spring Creek and six other springs within several kilometers of Big Spring Creek (Fig. 2). Seven of the springs are located in the Conodoguinet Creek drainage basin: Big Spring (both east and west source springs), Cool Spring, Green Spring, Bullshead Branch, Mt. Rock Spring, and Alexander Spring. The two spring sources of Big Spring are located about $4.5 \mathrm{~km}$ south of Newville and collectively discharged an average of $765 \mathrm{~L} \mathrm{~s}^{-1}$ during this study (USGS, unpublished data). The Cool Spring resurgence occurs near the channel of Big Spring Creek in the Borough of Newville, and is the source of Newville municipal water supply. Discharge and source areas for this spring have not 


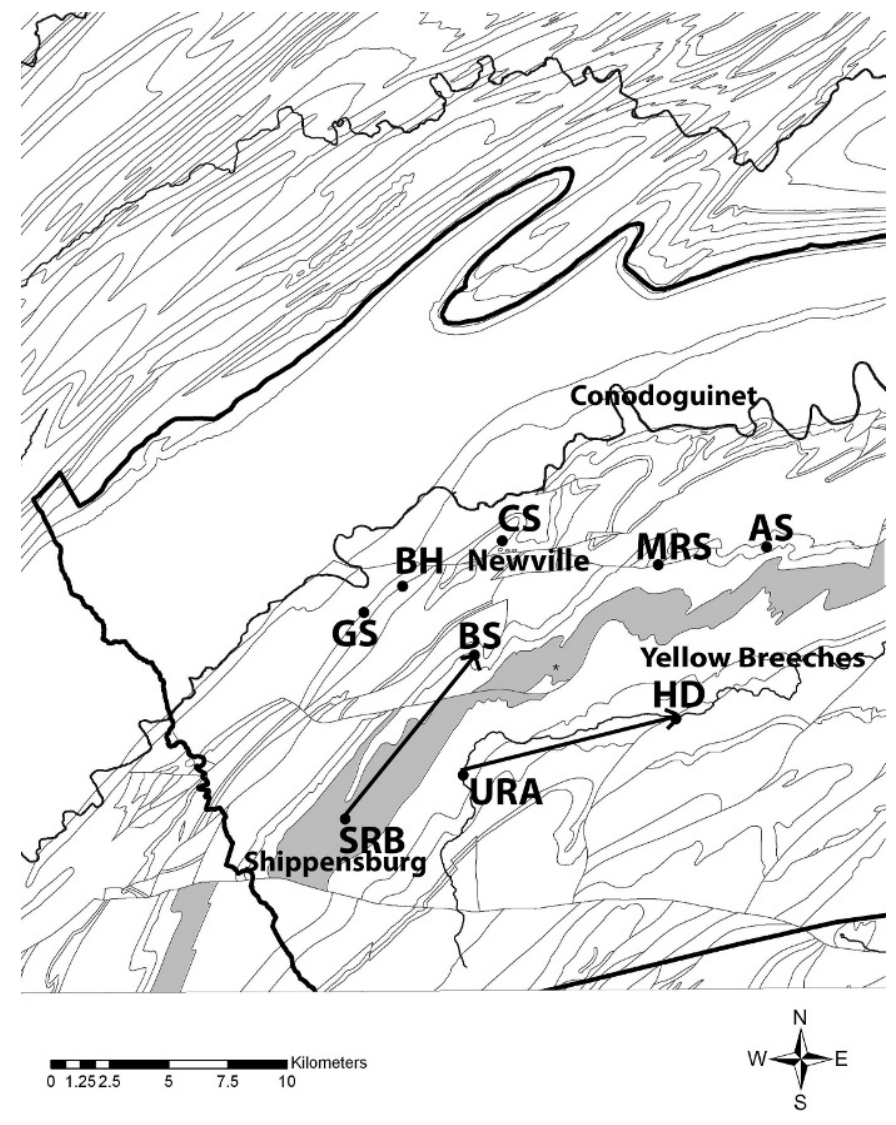

Figure 2. Release points, study springs, and groundwater flow paths (arrows) determined by fluorescent dye tracing in western Cumberland County, Pennsylvania. Tracer release points SRB - Sulpho Rhodamine-B dye, URA - sodium fluorescein dye. Study springs GS - Green Spring, BH Bullshead Spring, BS - Big Spring, CS - Cool Spring (Newville, Pennsylvania, municipal supply), MRS - Mount Rock Spring, AS - Alexander Spring, HD - Huntsdale Hatchery Springs. The asterisk denotes location of a recently permitted quarry $2.1 \mathrm{~km}$ east and south of Big Spring Creek sources. Extensive tectonic deformation has folded the rock so that it generally has a steep dip to the northwest, with a northeast-southwest strike. The Zullinger Formation is shaded. Note south of Big Spring an example of major faulting in the region.

been determined. Green Spring, which currently supplies water to a private fish hatchery, originates about $6.4 \mathrm{~km}$ southwest of Newville. Discharge was estimated once in 2005 to be approximately $670 \mathrm{~L} \mathrm{~s}^{-1}$. Bullshead Branch is a spring tributary to Green Spring Creek, located about $6.4 \mathrm{~km}$ from Newville. Discharge for Bullshead Branch was not measured, but appears comparable to or less than that of Green Spring. Bullshead Branch and Green Spring possess relatively long, intermittent surface channels above their resurgence points. Mt. Rock Spring discharged approximately $500 \mathrm{~L} \mathrm{~s}^{-1}$ during spring and summer measurements in 2005 and is about $7.6 \mathrm{~km}$ east of Newville.
Alexander Spring emerges from several spring seeps with lower total discharge than the other springs studied and is about $12 \mathrm{~km}$ east of Newville. The streams flowing from Mt. Rock Spring and Alexander Spring lose water in their lower reaches, with frequent lack of surface flow to Conodoguinet Creek during the summer and fall (Earle, 2009). A group of springs located in the mantled karst of the Yellow Breeches Creek drainage basin was sampled at their confluence at Huntsdale State Fish Culture Station of the Pennsylvania Fish and Boat Commission (Fig. 2).

We used fluorescent dye tracing to determine groundwater-flow patterns, with sodium fluorescein (C.I. Acid Yellow 73) and Sulpho Rhodamine B (C.I. Acid Red 52) chosen for tracers based on their low detection limits and safety to humans and organisms (Field et al., 1995; Käss, 1998). Charcoal receptors were purchased from the Crawford Hydrology Laboratory and consisted of vinylcoated fiberglass-screen mesh filled with $10 \mathrm{~g}$ of activated coconut charcoal. Pairs of background receptors were exchanged from springs weekly during the summer of 2005, until suitable tracer-release conditions occurred, defined as one week of complete sinking of the surface flow in the upper Yellow Breeches. Duplicate receptors continued to be exchanged weekly for seven weeks following dye injection. Water from the two main source springs of Big Spring Creek was collected in $60 \mathrm{ml}$ brown glass bottles, beginning immediately before the first dye release and then daily thereafter. The background fluourescence corresponded to only $15 \mathrm{ppt}$ for Sulpho Rhodamine B in the pre-release water samples from the source springs and 7 to $25 \mathrm{ppt}$ for sodium fluorescein in detectors collected the week before release, resulting in low detection limits in the post-release samples. Receptors and water samples were kept dark and cool in an ice chest during transport and refrigerated afterward.

On the afternoon of August 25, 2005, receptors were exchanged and water samples were collected for background fluorescence. At 8:00 p.m. that day, $0.9 \mathrm{~kg}$ of sodium fluorescein dye dissolved in $9.5 \mathrm{~L}$ of water was released in the sinking reach of the Yellow Breeches at Route 174 in Walnut Bottom, Pennsylvania, directly south of Big Spring (Fig. 2). This reach was losing water along its entire surface flow to within $50 \mathrm{~m}$ downstream of the release point. By dawn on August 26, only a trace of the dye was visible along the stream edge in back-current areas, and there was no dye visible by 11:00 a.m. At 9:00 p.m. on August 27, 2005, $0.9 \mathrm{~kg}$ of Sulpho Rhodamine B dissolved in $9.5 \mathrm{~L}$ of water was released into a sinkhole collapse in the Zullinger Formation during a rain event. This site is located within an engineered detention basin near the surface watershed boundaries of Middle Spring and Bullshead Branch, west of Big Spring (Figs. 1, 2). It drains impervious runoff via open culverts under Interstate Highway 81.

Charcoal receptors were eluted and the solution was analyzed with a Shimadzu scanning spectrofluoropho- 
FAST, REGIONAL CONDUIT FLOW TO AN EXCEPTIONAL-VALUE SPRING-FED CREEK: IMPLICATIONS FOR SOURCE-WATER PROTECTION IN MANTLED KARST of South CEnTRal Pennsylvania

tometer at the Crawford Hydrology Lab (Crawford and Associates, 2004). We also used a Shimadzu scanning spectrofluorophotometer to analyze water samples.

The average daily Sulpho Rhodamine B concentration was estimated from the breakthrough curve at Big Spring west and combined with hourly discharge data (USGS, unpublished) to estimate the approximate mass of recovered tracer, assuming that the west spring contributed $90 \%$ of the discharge and $90 \%$ purity of the Sulpho Rhodamine $\mathrm{B}$ released. Mean discharge for the breakthrough period (USGS unpublished) and mean transit time were also used to obtain preliminary estimates of conduit system volume and radius (Goldsheider et al., 2008). To estimate system volume for the west spring, average discharge of $688 \mathrm{~L} \mathrm{~s}^{-1}$ (90\% of average $765 \mathrm{~L} \mathrm{~s}^{-1}$ for both source springs; USGS unpublished) was multiplied by mean transit time (6 days), the time when one half of the detected tracer passed the sampling site. We then estimated conduit radius based on flow distance and system volume, assuming one phreatic pipe.

The approximate drainage area for Big Spring Creek (both source springs) was estimated using values of precipitation $(98.6 \mathrm{~cm})$ and evaporation $(63.3 \mathrm{~cm})$ at Shippensburg, Pennsylvania (Chichester, 1996; Rense, $1997)$ and four years of mean discharge $\left(849.5 \mathrm{~L} \mathrm{~s}^{-1}\right)$ from USGS (2009). We assumed mean discharge during this time approximated mean discharge during the period of precipitation record.

\section{RESULTS}

Both injected dyes followed regional, linear patterns paralleling the valley topography and trend in strike, with resurgence at specific springs (Fig. 2). Sulpho Rhodamine $\mathrm{B}$ was detected in water samples 3.5 days after release, $8.9 \mathrm{~km}$ to the northeast in the west source spring of Big Spring (Figs 2, 3), indicating a maximum effective linear velocity of $2.5 \mathrm{~km} \mathrm{~d}^{-1}$ in the exposed carbonates. Peak concentrations of 250 to 316 ppt occurred between August 31 and September 3, 2005, then tailed, indicating a mean transport time of 6 days and mean linear velocity of $1.5 \mathrm{~km} \mathrm{~d}^{-1}$. A longer period of detection existed for the charcoal receptors at this site, continuing through September and into the first week of October (Fig. 3). The Crawford Laboratory designated the dye connection to the west spring as extremely positive, their most confident designation for charcoal receptors, with peak eluate concentration of 45 to $50 \mathrm{ppb}$. In the east source of Big Spring, Sulpho Rhodamine B dye was not clearly detectable from the charcoal receptors until the week of September 1-8 (approximately 2 ppb in eluate), then tailed to even lower levels by October 2005 (Fig. 3). The Sulpho Rhodamine B detection limit for water samples at the east source of Big Spring was $10 \mathrm{ppt}$, but we did not detect the dye in water samples there.
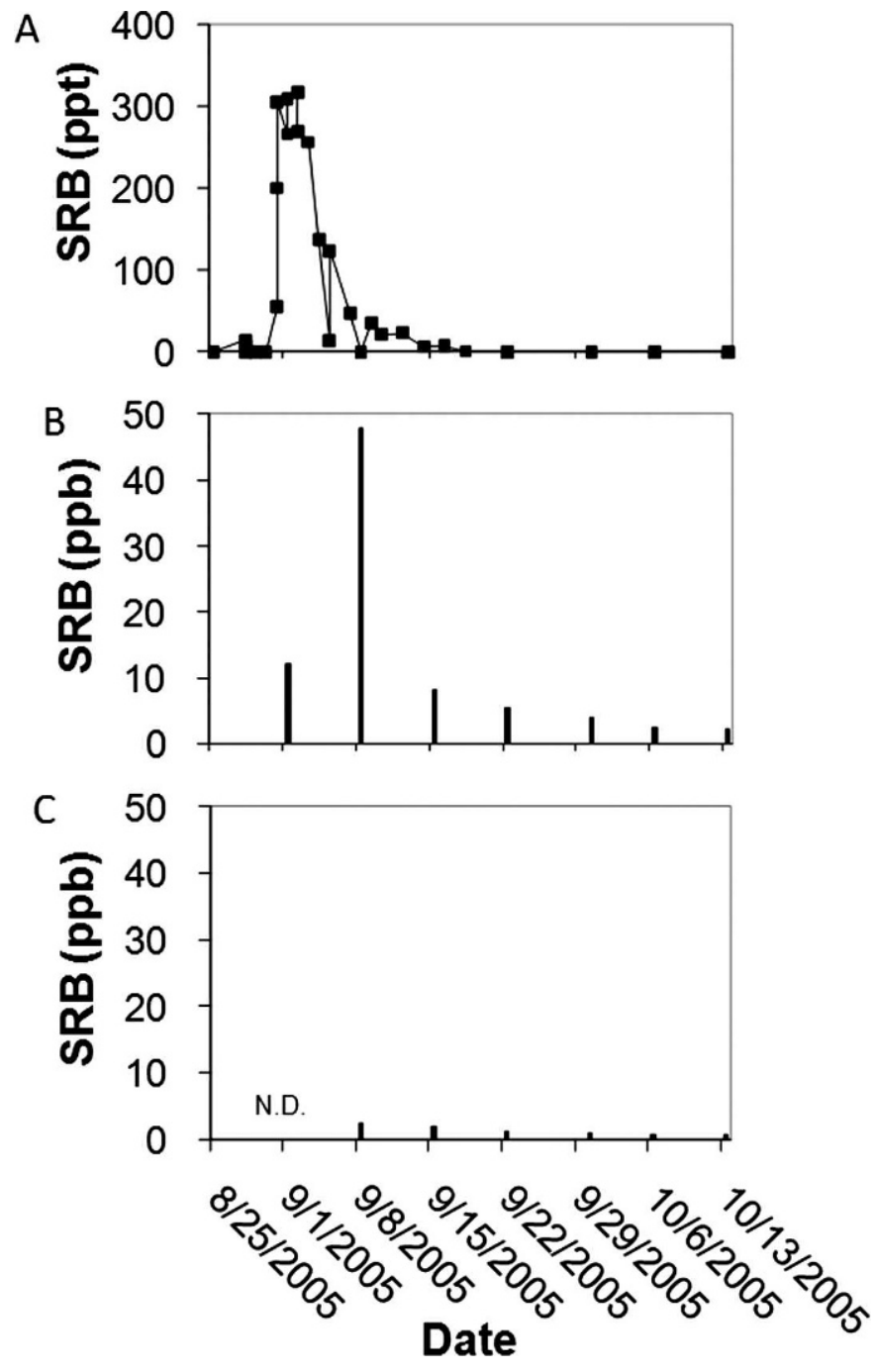

Figure 3. Differential breakthrough of Sulpho Rhodamine B (SRB) at Big Spring source springs following injection on August 27, 2005. A. Strong and rapid breakthrough curve at the larger west source spring based on water samples. B. Strong dye detection at the larger west source spring on receptors. C. Dye detection at the smaller east source spring on receptors. SRB was not detected clearly in water samples for the east spring.

Calculations of dye-mass recovery for Sulpho Rhodamine B suggest that approximately $9 \%$ of the released tracer was recovered in the west source of Big Spring, using the data shown in Figure 4. A preliminary estimate for volume of the west source conduit is approximately $357,000 \mathrm{~m}^{3}$, with a conduit radius of $3.6 \mathrm{~m}$.

The sodium fluorescein released $5.2 \mathrm{~km}$ south of Big Spring was detected $9.5 \mathrm{~km}$ east of the release point, at the springs at Huntsdale Hatchery, approximately one month after release as 77 to $140 \mathrm{ppt}$ in the eluate from charcoal (Fig. 2). This dye was not detected in Big Spring or other springs draining to the north, but apparently remained in the Yellow Breeches surface watershed. Flow to the 


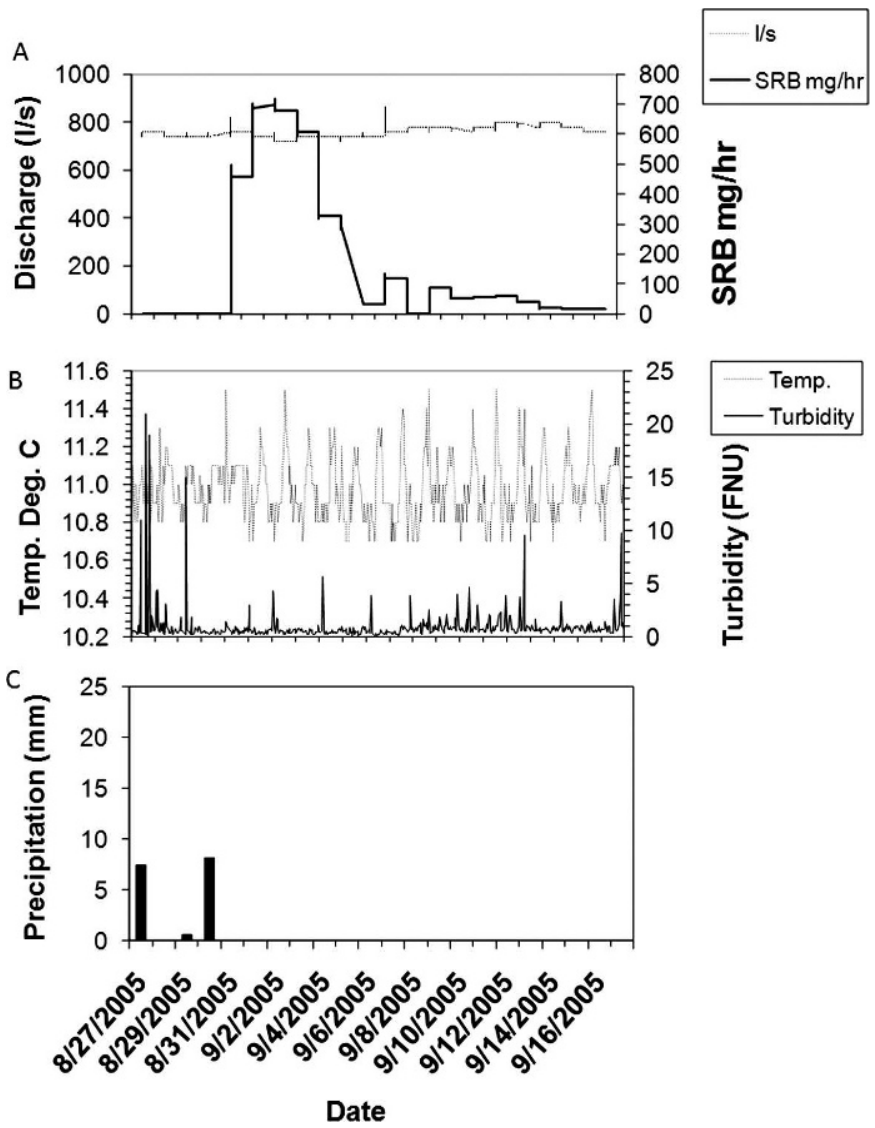

Figure 4. A. Estimated mass breakthrough of Sulpho Rhodamine B in Big Spring with discharge, assuming $90 \%$ contribution of west source spring to total flow, and $90 \%$ tracer purity. B. Temperature and turbidity of Big Spring. C. Precipitation recorded at Shippensburg University. Discharge, temperature, and turbidity data were provided courtesy of the U.S. Geological Survey (Bruce Lindsey).

Huntsdale springs was comparatively slow through the mantled karst, approximately $0.3 \mathrm{~km} \mathrm{~d}^{-1}$ versus 1.5 to $2.5 \mathrm{~km} \mathrm{~d}^{-1}$ in the exposed carbonates. Using precipitation (Chichester, 1996) and evaporation (Rense, 1997) estimates for Shippensburg, Pennsylvania, and discharge for Big Spring Creek (USGS, 2009), we estimated approximate drainage area of $76 \mathrm{~km}^{2}$ for both of the main source springs of Big Spring Creek. Further dye tracing will lead to a better understanding of the extent of the Big Spring drainage basin.

\section{DisCUSSION}

Regional groundwater flow patterns closely followed trends in geologic strike from west and south (Fig. 2). For Big Spring Creek, flow from outside the surface watershed can be rapid and follow preferential flow paths from karst recharge features to primary springs. This pattern is common in Appalachian karst (Ginsberg and Palmer,
2002) and confirms the importance of rapid surface contribution to conduits where the colluvial mantle thins. The west and east sources of Big Spring Creek had very different breakthrough responses (Fig. 3), which suggests that the two source springs have distinct flow paths or that the east spring discharges more diffuse flow. The west source of Big Spring can become turbid during very strong precipitation events, a characteristic of fast flow systems (Quinlan, 1989; Otz and Azzolina, 2007; Herman et al., 2008). Nevertheless, this spring usually demonstrates relatively low variability in discharge, temperature, and turbidity (USGS, 2009). These patterns suggest cavestream flow from the Sulpho Rhodamine B release point, fed by moderated flow from the colluvial mantle. White and White (2001) note that many groundwater basins in Appalachian karst consist of a branch-work cave flow system, where subterranean tributaries interacting with allogenic surface water feed dominant conduit flow. These authors also note how flow through Appalachian karst can be moderated by flow into smaller fractures from main conduits during events, with subsequent slower drainage back to the conduit system. Lindsey et al. (2006) noted dual flow characteristics of Dykeman Spring, in the Middle Spring Creek watershed, and Big Spring, based on geochemical measurements, hydrological monitoring, and results of this study. It is reasonable to envision relatively slow flow in colluvium or colluvial fill, followed by rapid delivery to springs via conduit flow. White (2007) notes that carbonate springs may be fed by conduits, yet exhibit little or no hydrograph response to storms due to primary storage in the epikarst. Smeltzer (1958) mapped a number of caves in the Shippensburg area, most of which consist of interconnected main passages that trend northeast-southwest along the strike, although most do not currently carry streams. White (1958) notes that Shippensburg-area caves are probably remnants of a formerly more complex cavern system, dating possibly to the late Tertiary, and that this long history has likely contributed to complex patterns of fillings and re-excavations. Such history would also contribute to the complex hydrology of the mantled karst.

Karst systems are extremely vulnerable to anthropogenic impacts and may rapidly transport water and contaminants on a regional scale (Vesper et al., 2001). Surface runoff to the collapsed sinkhole where Sulpho Rhodamine B was released originates in zones of residential and industrial development, flows through an engineered drainage system open to contaminant spills near an interstate-highway exit (the IH 81 and Highway 174 interchange), and sinks immediately upon entering a failed storm-water detention basin (Fig. 5a). Maximum effective linear velocity of groundwater flow from this recharge feature to the west source of Big Spring Creek was $2.5 \mathrm{~km} \mathrm{~d}^{-1}$, higher than velocities $\left(0.02\right.$ to $\left.1.7 \mathrm{~km} \mathrm{~d}^{-1}\right)$ derived from first-arrival times for groundwater in the region between an army depot and springs farther west and north (Aley et al., 2004).

Journal of Cave and Karst Studies, December 2010 133 
A

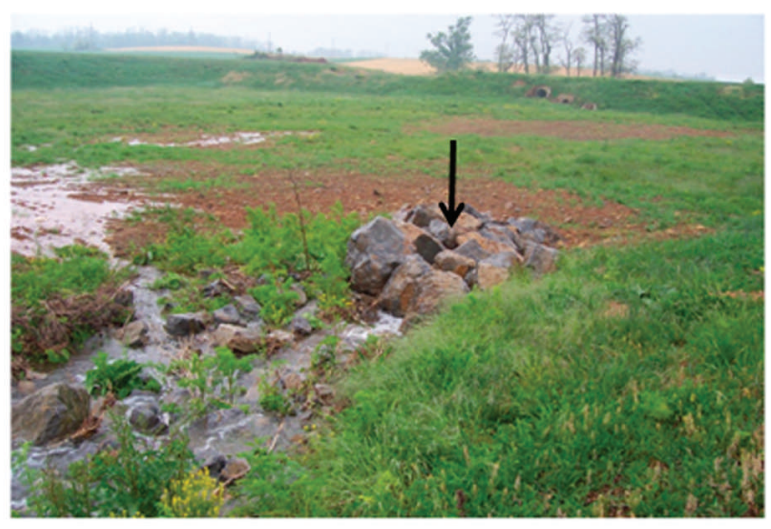

B

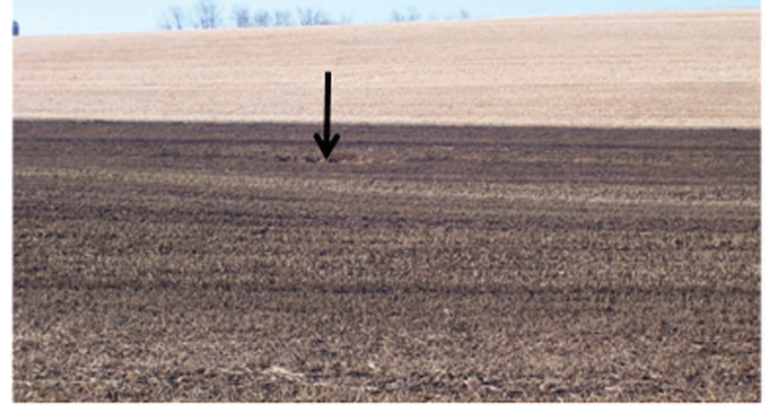

C

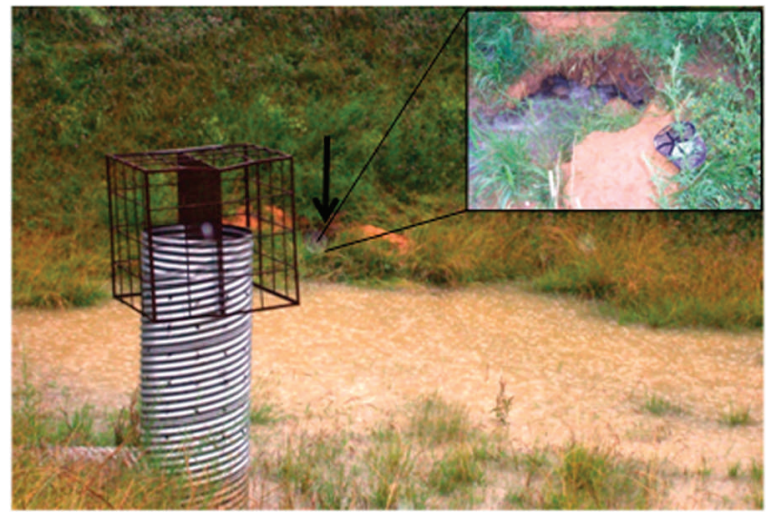

Figure 5. Critical recharge areas associated with karst features in Cumberland County, Pennsylvania. A. Runoff from impervious surface and interstate-highway drainage into a failed detention basin. This was the release point of Sulpho Rhodamine B traced to the west source spring of Big Spring Creek. B. Liquid manure spread over an active sink where the colluvial mantle thins. C. Sink collapse in an infiltration gallery of a recently permitted quarry and asphalt production facility, $2.1 \mathrm{~km}$ southeast of Big Spring source springs.

Karst recharge features in close proximity to intensive agricultural or urban land use present a direct threat to Big Spring Creek and sensitive receptors. Such features should be better buffered or controlled when associated with intensive land use (Petersen and Vondracek, 2006) to allow for more gradual infiltration and natural attenuation of potential contaminants from agricultural and industrial areas. Similar drainage into the subsurface occurs in the region within fields receiving agricultural runoff, in a military installation leaching volatile organics (Aley et al., 2004), and in a quarry and asphalt plant within $2 \mathrm{~km}$ of Big Spring Creek (Fig. 5).

Our results do not support previous suggestions that groundwater flows predominantly across the valley from South Mountain toward Big Spring and Conodoguinet Creek (Becher and Root, 1981; Chichester, 1996; Continental Placer, 2003), although there is need for further dyetracing tests under varying hydrological conditions to better determine these patterns. Well data showing northward flow with hydraulic conductivity of only 0.2 to $1.1 \mathrm{~m} \mathrm{day}^{-1}$ (Continental Placer, 2003) on the southeast boundary of the Big Spring surface watershed may be reflecting slower fracture flow within the Zullinger Formation, in which we demonstrated rapid conduit flow (Fig. 2). There is need for dye tracing of conduit systems to be incorporated into permitting and monitoring processes (Quinlan, 1989) in Pennsylvania karst, particularly when development occurs in close proximity to Exceptional Value spring-fed creeks and municipal springs.

Sodium fluorescein released in the upper Yellow Breeches watershed appeared to remain in this watershed (Fig. 2). Neither tracer was detected in Cool Spring, Green Spring, Bullshead Branch, Mt. Rock Spring, or Alexander Spring, suggesting that these are separate flow systems. Nevertheless it is important to acknowledge that false negative results can be obtained for a number of reasons in fluorescent dye-tracing tests (Quinlan, 1989), and so they should be interpreted cautiously. Groundwater flow from the Yellow Breeches release site was substantially slower than from the other release site, with sodium fluorescein taking about one month to travel the distance it took the Sulpho Rhodamine B to travel in 3 to 5 days. This is likely due to the slowing of surface water as it infiltrates the colluvial material along South Mountain prior to phreatic flow toward springs associated with Yellow Breeches Creek. Detection of sodium fluorescein at the Huntsdale springs was not as strong as Sulpho Rhodamine B in the valley center and did not meet the criterion of two consecutive detections at 10-times background for a certain positive following the Crawford Laboratory protocol (Crawford and Associates, 2004). Nevertheless, sodium fluorescein was detected at least 3 to 5 times background for two consecutive weeks one month following release. At Huntsdale, there are multiple springs combined into a larger hatchery source. Collectively, the geologic setting and complexity of the Huntsdale springs and hatchery system may call for further source water delineation with different tracers and injection locations.

We estimate that the drainage area for Big Spring is approximately $76 \mathrm{~km}^{2}$, whereas the surface watershed area is only $8.8 \mathrm{~km}^{2}$. Given that the springs are within 
approximately 5 to $10 \mathrm{~km}$ of one another and dye traveled $9 \mathrm{~km}$ along strike, subterranean basins associated with these systems may be narrow and parallel to one another. This conceptual model fits well with the "rule of thumb" approach for estimating source areas in Appalachian karst, where vadose flow follows dip from local topographic highs, then turns $90^{\circ}$ to follow phreatic conduits along the strike (Ginsberg and Palmer, 2002). The pattern is also consistent with contamination of Cumberland County groundwater in 1969 by a gasoline spill close to Harrisburg (Becher and Root, 1981), other Appalachian karst systems (e.g. Dasher and Boyer, 1997; White and White, 2001; Herman et al., 2008), and trends of major cave passages in the region (Smeltzer, 1958). We made preliminary estimates for system volume $\left(357,000 \mathrm{~m}^{3}\right)$ and radius (3 to $4 \mathrm{~m}$ ) assuming one phreatic pipe. While this approach is useful for preliminary conceptualization, it is likely that the associated conduit system includes both open passage and flooded sumps, as other mapped Pennsylvania caves demonstrate (Smeltzer, 1958; White, 2007). Low recovery of Sulpho Rhodamine B also suggests hydrological complexity. This low recovery is likely due to adsorption and dilution in the aquifer due to the small quantity used $(1 \mathrm{~kg})$ and the distance traveled $(9 \mathrm{~km})$. Some SRB was missed after concentrations fell below detection limits. (Fig. 3).

\section{Conclusions}

We have documented fast, regional conduit flow along strike (approximately $3 \mathrm{~km} \mathrm{~d}^{-1}$ based on first arrival time) and vulnerability to intensive land use for a high-quality/ exceptional-value spring-fed creek in Pennsylvania, Big Spring Creek. Slower flow from losing streams over the colluvial mantle likely maintains the relatively high quality of Big Spring Creek and similar springs in the region. Nevertheless, these recharge areas are distant, with groundwater traveling through conduits open to surface runoff in exposed carbonates of the valley center.

In the study area, nutrients and other contaminants in the discharge of karst springs can come from recharge features along the path of the underground flow, and not principally from losing surface streams. Therefore, mitigation focus and best management practices should be redirected from riparian buffers to spring head, well head, and source area protection, along with improved storm water engineering, joint municipal planning, and permitting in these areas. Regional planning and source-water protection strategies (e.g., Doerfliger et al., 1997; Kastning and Kastning, 1997; Kacaroglu, 1999) need to be implemented based on definitive hydrological studies and identification of critical recharge features along delineated karst groundwater flows. Such focus would not only protect local spring water and its existing uses, but would more effectively reduce non-point nutrient, sediment, and contaminant loadings to the Susquehanna/Chesapeake Bay watersheds via karst valleys.

\section{ACKNOWLEDGEMENTS}

We thank Drs. Nicholas Crawford (Center for Cave and Karst Studies), Donald Siegel (Syracuse University), and Heinz Otz (Otzhydro, Switzerland) for assistance in the study design, along with Doug Chichester of U.S. Geological Survey. Bruce Lindsey of U.S. Geological Survey provided data shown in Figure 4. We also thank the Crawford Hydrology Laboratory for charcoal-receptor analysis and Big Spring Watershed Association, Inc. and land owners whose support was invaluable. An Alexander Stewart Foundation Grant to Big Spring Watershed Association and a Pennsylvania State System of Higher Education Professional Development Grant to T.M. Hurd provided funding for the study.

\section{REFERENCES}

Aley, T., Tucker, M., and Stone, P.R. III, 2004, Letterkenny Army Depot Southeastern Area National Priorities List site, Operable Unit Six offpost groundwater, Appendix A-4 Groundwater Tracing Study, OffPost Trace 3. Prepared by Ozark Underground Laboratory. Protem, Missouri, in SEOU6 Southeastern Area Off-Post Groundwater Remedial Investigation Report LEADSEOU6RI1104 compiled by Shaw Environmental, Inc., Cherry Hill, New Jersey, 141 p.

Becher, A., and Root, S., 1981, Groundwater and Geology of the Cumberland Valley, Cumberland County, Pennsylvania: Pennsylvania Geological Survey, 4th ser., Water Resource Report 50, 95 p.

Chichester, D.C., 1996, Hydrogeology of, and simulation of ground-water flow in, a mantled carbonate-rock system, Cumberland Valley, Pennsylvania: U.S. Geological Survey Water-Resources Investigations Report 94-4090, 39 p

Continental Placer, 2003, Quarry Dewatering Impact Evaluation, Produced for Pennsy Supply Inc., Penn Township Operation, Penn Township, Pennsylvania, December 2003, Continental Placer, Inc., 7 p.

Cooper, E.L., and Scherer, R.C., 1967, Annual production of brook trout (Salvelinus fontinalis) in fertile and infertile streams of Pennsylvania, in Proceedings of the Pennsylvania Academy of Science, v. 41, p. $65-70$.

Crawford and Associates, 2004, Laboratory Profile, Center for Cave and Karst Studies, Applied Research and Technology Program of Distinction, Department of Geography and Geology, Bowling Green, Kentucky, Crawford and Associates, 73 p.

Dasher, G., and Boyer, D., 1997, Dye tracings in the Spring Creek area, Greenbrier County, West Virginia, in Younos, T., Burbey, T.J., Kastning, E.H., and Poff, J.A., eds., Proceedings, Karst Water Environment Symposium, October 30-31, 1997, Roanoke, VA: Virginia Water Resource Center, v. P3-1997, p. 18-30.

Doerfliger, N., Jeannin, P.-Y., and Zwahlen, F., 1997, EPIK: A new method for outlining of protection areas in karstic environments, in Günay, G., and Johnson, A.I., eds., Karst Waters and Environmental Impacts, Rotterdam, Balkema, p. 117-123.

Earle, J., 2009, Watershed Restoration Action Strategy, State Water Plan Sub basin 07B, Conodoguinet Creek Watershed, Franklin and Cumberland Counties: Pennsylvania Department of Environmental Protection, Bureau of Watershed Management. http://www.dep.state. pa.us/dep/DEPUTATE/Watermgt/WC/Subjects/WSNoteBks/WRAS07B.htm [accessed September 10, 2009].

Field, M.S., Wilhelm, F.G., Quinlan, J.F., and Aley, T.J., 1995, An assessment of the potential adverse properties of fluorescent tracer dyes used for groundwater tracing: Environmental Monitoring and Assessment, v. 38, p. 75-96.

Ginsberg, M., and Palmer, A., 2002, Delineation of Source-Water Protection Areas in Karst Aquifers of the Ridge and Valley and 
Appalachian Plateaus Physiographic Provinces: Rules of Thumb for Estimating the Capture Zones of Springs and Wells: U.S. Environmental Protection Agency, EPA 816-R-02-015, 41 p.

Goldsheider, N., Meiman, J., Pronk, M., and Smart, C., 2008, Tracer tests in karst hydrogeology and speleology, International Journal of Speleology, v. 37, no. 1, p. 27-40.

Greene, E.A., LaMotte, A.E., and Cullinan, K.A., 2004, Ground-water Vulnerability to Nitrate Contamination at Multiple Thresholds in the Mid-Atlantic Region Using Spatial Probability Models: U.S. Geological Survey Scientific Investigations Report 2004-5118, 24 p.

Herman, E.K., Toran, L., and White, W.B., 2008, Threshold events in spring discharge: Evidence from sediment and continuous water level measurement: Journal of Hydrology, v. 351, p. 98-106.

Hollyday, E.F., Hileman, G.E., and Duke, J.E., 1997, The Elkton aquifer or Western Toe aquifer of the Blue Ridge Mountains - A regional perspective, in Younos, T., Burbey, T.J., Kastning, E.H., and Poff, J.A., eds., Proceedings, Karst Water Environment Symposium, October 30-31, 1997, Roanoke, Va.:Virginia Water Resource, v. P31997, p. 71-77.

Hurd, T.M., Jesic, S., Jerin, J.L., Fuller, N.W., and Miller, D. Jr., 2008, Stable isotope tracing of trout hatchery carbon to sediments and foodwebs of limestone spring creeks: Science of the Total Environment, v. 405, p. 161-172. doi:10.1016/j/scitotenv.2008.06.036.

Kacaroglu, F., 1999, Review of groundwater protection and pollution in karst areas, Water Air and Soil Pollution:, v. 113, p. 337-356.

Käss, W., 1998, Tracing technique in geohydrology, Rotterdam, Balkema, $581 \mathrm{p}$.

Kastning, E.H., and Kastning, K.M., 1997, Buffer zones in karst terrains, in Younos, T., Burbey, T.J., Kastning, E.H., and Poff, J.A., eds., Proceedings, Karst Water Environment Symposium, October 30-31, 1997, Roanoke, Va.: Virginia Water Resource Center, v. P3-1997, p. $80-87$.

Lindsey, B.D., Phillips, S.W., Donnelly, C.A., Speiran, G.K., Plummer, L.N., Böhlke, J.K., Focazio, M.J., Burton, W.C., and Busenberg, E., 2003, Residence Times and Nitrate Transport in Groundwater Discharging to Streams in the Chesapeake Bay Watershed: U.S. Geological Survey Water-Resources Investigations Report 03-4035, $201 \mathrm{p}$.

Lindsey, B.D., Berndt, M.P., Katz, B.G., Ardis, A.F., and Skach, K.A., 2009, Factors affecting water quality in selected carbonate aquifers in the United States, 1993-2005: U.S. Geological Survey Scientific Investigations Report 2008-5240, 177 p.

Lindsey, B.D., Brookhart, A., Hurd, T.M., Feeney, T.P., Otz, M., and Otz, I., 2006, Multi-velocity transport of water through mantled karst aquifers: The potential effect on aquifers used for water supply: The Geological Society of America Northeastern Section - $41^{\text {st }}$ Annual Meeting, March 20-22, 2006, Camp Hill/Harrisburg, Pennsylvania, Abstracts, v. 38, no. 2, 74 p.
Low, D.J., and Chichester, D.C., 2006, Ground-Water-Quality Data in Pennsylvania-A Compilation of Computerized [Electronic] Databases, 1979-2004: U.S. Geological Survey Data Series 150, 22 p.

Otz, M.H., and Azzolina, N.A., 2007, Preferential ground-water flow: Evidence from decades of fluorescent dye tracing: Geological Society of America, October 28-31, 2007, Denver, CO, Abstracts with programs, v. 39 , no. 6,350 p.

Pennsylvania Code Chapter 93: Water Quality Standards. http://www. pacode.com/secure/data/025/chapter93/chap93toc.html, [accessed September 10, 2009].

Petersen, A., and Vondracek, B., 2006, Water quality in relation to vegetative buffers around sinkholes in karst terrain: Journal of Soil and Water Conservation, v. 61, no. 6, p. 380-390.

Quinlan, J.F., 1989, Ground-water monitoring in karst terraines: Recommended protocols and implicit assumptions (unpublished), U.S. Environmental Protection Agency Report EPA/600/X-89/050, $79 \mathrm{p}$.

Rense, W.C., 1997, A 65-year water budget history of Shippensburg, Pennsylvania: Pennsylvania Geographical Society Annual Meeting, York, Pennsylvania, November 1997.

Smeltzer, B., 1958, Additional data on Shippensburg caves, in White, W.B., ed., MAR Bulletin 4, University Park, Pennsylvania, MidAppalachian Region of the NSS, p. 3-17.

United States Geological Survey (USGS), 2009, National Water Information System. Department of the Interior, U.S. Geological Survey, http://waterdata.usgs.gov/nwis/uv?01569460 [accessed September 10, 2009].

Vesper, D.J., Loop, C.M., and White, W.B., 2001, Contaminant transport in karst aquifer: Theoretical and Applied Karstology, v. 13-14, p. 101-111. [Reprinted 2003: Speleogenesis and Evolution of Karst Aquifers, v. 1, no. 2, 11 p., http://www.speleogenesis.info/pdf/SG2/ SG2_artId19.pdf.]

Walderon, M., and Hurd, T.H., 2009, Nutrient dynamics in carbonate vs. non-carbonate streams: Seasonality, sources, and relative loading: $94^{\text {th }}$ Annual Meeting of the Ecological Society of America, Abstract with Programs, COS 19-4 Biogeochemistry: Above Ground -Below Ground Interactions, in press.

White, W.B., 1958, Note on the geology of the Shippensburg area, in White, W.B., ed., MAR Bulletin 4, University Park, Pennsylvania, Mid-Appalachian Region of the NSS, p. 1-2.

White, W.B., 2007, A brief history of karst hydrogeology: Contributions of the NSS: Journal of Cave and Karst Studies, v. 69, no. 1, p. 13-26.

White, W.B., and White, E.L., 2001, Conduit fragmentation, cave patterns, and the localization of karst groundwater basins: The Appalachians as a test case: Theoretical and Applied Karstology, v. 13-14, p. 9-23. [Reprinted 2003: Speleogenesis and Evolution of Karst Aquifers v. 1 no. 2, www.speleogenesis.info/pdf/SG2/SG2 artId22.pdf, 15 p.] 